\title{
The presence of thrust-block naled after a major surge event: Kuannersuit Glacier, West Greenland
}

\author{
Jacob C. YDE, ${ }^{1}$ N. Tvis KNUDSEN, ${ }^{1}$ Nicolaj K. LARSEN, ${ }^{2}$ Christian KRONBORG, ${ }^{2}$ \\ Ole B. NIELSEN, ${ }^{2}$ Jan HEINEMEIER, ${ }^{3}$ Jesper OLSEN ${ }^{3}$ \\ ${ }^{1}$ Department of Earth Sciences, University of Aarhus, Ny Munkegade bygning 520, DK-8000 Aarhus, Denmark \\ E-mail: yde@geo.au.dk \\ ${ }^{2}$ Department of Earth Sciences, University of Aarhus, C.F. Møllers Allé bygning 120, DK-8000 Aarhus, Denmark \\ ${ }^{3}$ AMS C-14 Dating Centre, Department of Physics and Astronomy, University of Aarhus, Ny Munkegade bygning 520,
} DK-8000 Aarhus, Denmark

\begin{abstract}
Thrust-block naled in front of Kuannersuit Glacier, West Greenland, appears to have formed during the termination of a terrestrial surge event by a combination of enhanced winter runoff, rapid advance of the glacier terminus, and proglacial stress release by thrusting and stacking of naled blocks. This process is equivalent to the formation of thrust-block moraines. The thrust-block naled consists of at least seven thrust sheets, which are characterized by stratified ice with beds composed of a lower debris-rich lamina, an intermediate dispersed lamina and a top clean-ice lamina, and underlain by frozen outwash deposits. The thrust-block naled differs from basal stratified ice in the absence of internal deformation structures, a relatively low debris concentration, a clay-rich particle-size distribution and a preferential sorting of lighter minerals. The oxygen isotope composition of the thrust-block naled is indistinguishable from $\delta^{18} \mathrm{O}$ values from meteoric glacier ice and bulk meltwater, but different from basal stratified ice facies. The $d-\delta D$ relationship indicates that thrustblock naled has been formed by freezing of successive thin layers of bulk waters with variable isotopic composition, whereas basal stratified ice has developed in a subglacial environment with regelation. This work shows that the association between proglacial naled and rapidly advancing glaciers may have significant consequences for the proglacial geomorphology and the interpretation of basal ice layers.
\end{abstract}

\section{INTRODUCTION}

Two proglacial features are associated with rapid advance of a glacier terminus into an outwash plain in permafrost environments: (i) thrust-block moraines produced when a glacier terminus transfers longitudinal compressive stresses into the frozen proglacial outwash plain, causing failure and stacking of large faulted blocks (Evans and England, 1991; Evans and Rea, 1999); and (ii) glacier naled (plural naledi; also referred to as icing or aufeis), which is an extrusive stratified ice accretion formed when successive discharge of water in winter inundates frozen ground or existing river ice or lake ice (Åkerman, 1982). Glacier naled is characteristic of outwash plains, where high hydraulic potentials develop as a consequence of constrained drainage conditions, and it has potential to influence sedimentation and geomorphology on proglacial outwash plains (Åkerman, 1982; Baranowski, 1982; Bennett and others, 1998). Liestøl (1969) was one of the first to discuss the association between naled accretions and glacier surging; he noted that the only known small glacier in the Dickson Valley area, west Svalbard, with proglacial naled was a surge-type glacier in its initial quiescent phase. As a consequence of an unstable glacial drainage system, basal cavities and enhanced basal melt rates, the winter runoff emanating from surge-type glaciers is likely to increase during the active surge phase, thereby producing proglacial naled accretions.

We believe that this paper is the first to report on thrustblock moraines composed of debris-rich naled. These landforms are termed thrust-block naled accordingly.
Observations indicate that thrusting and stacking of naled blocks occurred in front of the terminus of Kuannersuit Glacier, West Greenland, during the final phase of a major surge event in 1995-98. Here, a model explaining the formation of thrust-block naled is presented.

\section{STUDY AREA}

Kuannersuit Glacier $\left(69^{\circ} 46^{\prime} \mathrm{N}, 53^{\circ} 15^{\prime} \mathrm{W}\right)$ is a $26 \mathrm{~km}$ long outlet glacier in central Disko Island, West Greenland (Fig. 1). The glacier belongs to the Disko-Nuussuaq surge cluster, described by Weidick (1988). The latest surge event of Kuannersuit Glacier began in 1995. By the winter of 1997/98, the glacier terminus had advanced about $10.5 \mathrm{~km}$ down-valley and terminated on land in the central part of Kuannersuit Kuussuat (Kuannersuit Valley) adjacent to an ice-cored outwash terrace. Although the frontal advance ceased in 1998, the glacier surface remained chaotically crevassed in 1999. Since then, many of the crevasses have closed and the glacier surface has levelled.

Naled assemblages are common features in the flatbottomed valleys of Disko Island, and those that are derived from surge-type glaciers often survive the ablation period. The stratigraphy of naledi is characterized by horizontal laminae composed of candle ice crystals with vertical growth axes (Hambrey, 1984). The winter runoff contributing to naled formation in front of Kuannersuit Glacier is assessed to constitute $1-2 \%$ of the estimated annual discharge of $653 \times 10^{6} \mathrm{~m}^{3}$ in 2001 (Yde and others, 2005). 


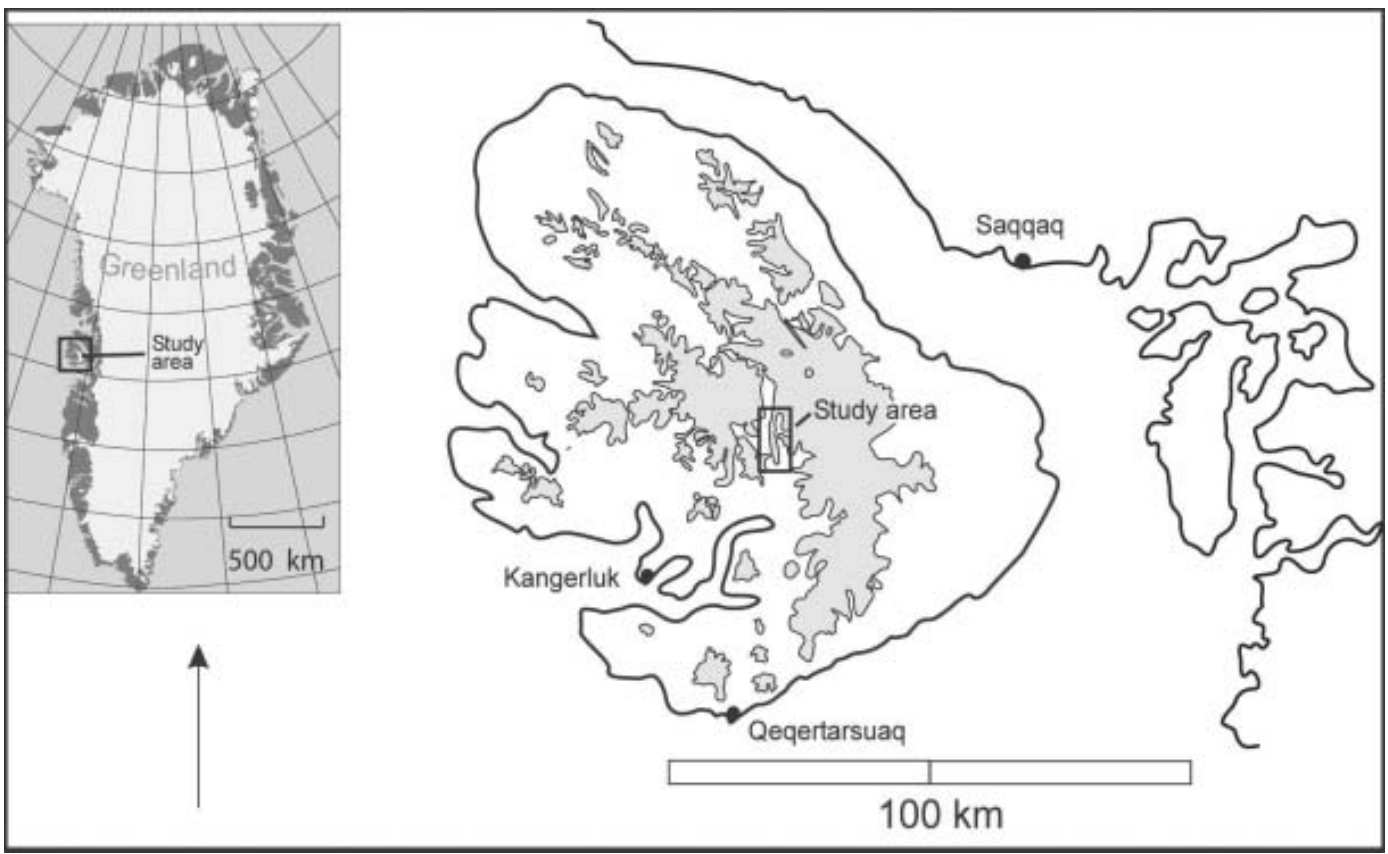

Fig. 1. Location map of Kuannersuit Glacier on Disko Island.

\section{GEOMORPHOLOGY}

At least seven sheets of thrust-block naled dipping towards the glacier were stacked in a $\sim 130 \mathrm{~m}$ wide zone between the ice-cored outwash terrace down-valley and up-sheared basal ice (Fig. 2). Thrust-block naled was not observed near the eastern corner of the glacier tongue and along the glacier margins. The thickness of the thrust-block naled sequences
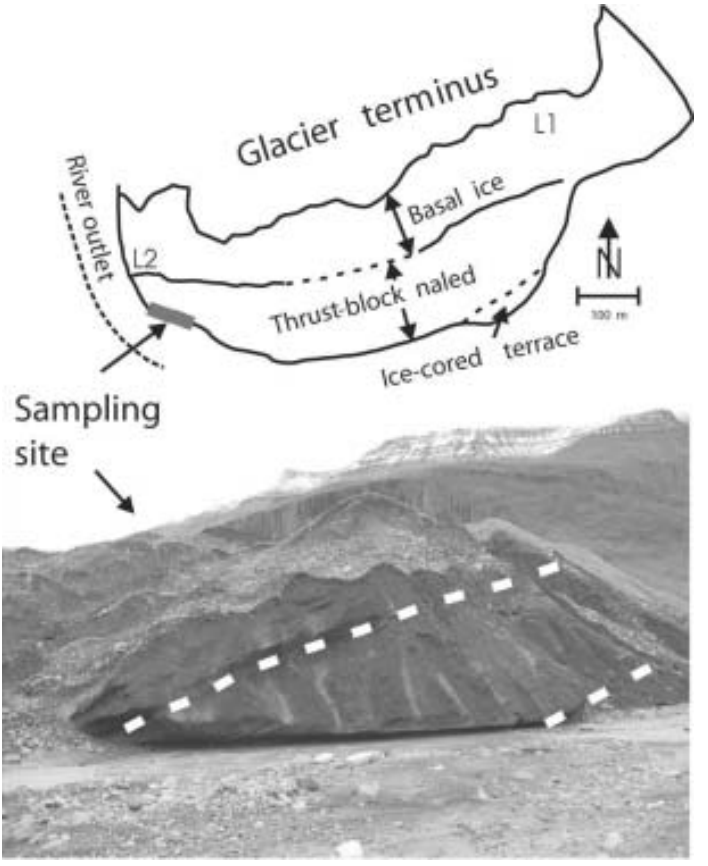

Fig. 2. Map showing the geomorphological context of the thrustblock naled. The locations L1 and L2 denote the basal ice sampling sites. The location of the sampling profile in the thrust-block naled is shown. The photo shows how one naled sheet was superimposed upon another. The framed naled sheet was at least $3.23 \mathrm{~cm}$ thick. comprised about $3 \mathrm{~m}$ of naled ice underlain by boulder-rich glaciofluvial outwash sediments at least $15 \mathrm{~cm}$ thick.

The adjacent basal ice dipped parallel with the thrustblock naled. It was characterized by a lower stratified debrisrich ice facies 1-2 $\mathrm{m}$ thick, an intermediate banded ice facies 25-30 m thick and an approximately $23 \mathrm{~m}$ thick upper ice facies that comprised 25-30 shear planes with meteoric glacier ice in between.

The proglacial outwash plain contained several ice-cored outwash terraces raised $3-5 \mathrm{~m}$ above the surrounding present outwash plain. These terraces most likely formed during the recession of the neighbouring Sorte Hak Glacier after its last surge, which occurred before 1898 (Steenstrup, 1901).

\section{THRUST-BLOCK NALED PROFILE}

In July 2003, a profile was cleaned at the western edge of the thrust-block naled area (Fig. 2). The $3.08 \mathrm{~m}$ thick naled consisted of 128 distinct beds with an average thickness of $2.4 \pm 2.1 \mathrm{~cm}$ (Fig. 3). The beds were composed of two or three laminae. Each bed was characterized by a debris-rich lamina and a clean-ice lamina, and the larger beds also comprised an intermediate dispersed lamina between clean ice above and debris-rich ice below, which contained aggregates in a matrix of debris-free ice (Fig. 4). Sublamination causing some variations in debris content occurred at an ice crystal scale. Both basal and top contacts were well defined, even in the thin layers of $0.2 \mathrm{~cm}$ that comprised only one or two ice crystals. The individual beds could be followed horizontally for several metres, and no internal deformation structures were observed in the thrustblock naled. However, the beds were highly variable in thickness, ranging from 0.2 to $14 \mathrm{~cm}$. Gas bubbles were generally absent, although some bubbles occurred at the interface between laminae and as sub-vertical strings a few centimetres in length interpreted as an indication of candle ice crystallography (Fig. 4). 


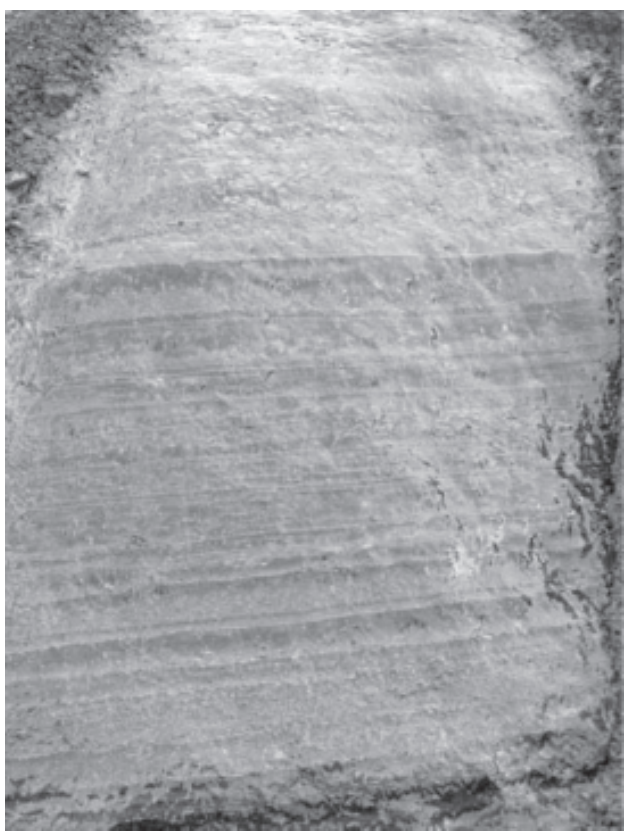

Fig. 3. Part of thrust-block naled profile with distinctive lamination. The profile covers $\sim 0.5 \mathrm{~m}$.

\section{ANALYTICAL METHODS}

Thrust-block naled samples were collected in polypropylene bags at $5 \mathrm{~cm}$ intervals along the vertical profile, and basal ice samples were collected at two locations denoted L1 and L2 in Figure 2. When the ice had thawed, water from each sample was carefully transferred to $20 \mathrm{~mL}$ vials for stableisotope analyses. Debris concentration was determined by evaporation using the remaining sample and assuming that the $20 \mathrm{~mL}$ water was debris-free. Glacier ice samples were collected for $\delta^{18} \mathrm{O}$ analyses along an $8 \mathrm{~km}$ longitudinal transect on the lower part of the ablation area and transferred to $20 \mathrm{~mL}$ vials after thawing. $\delta^{18} \mathrm{O}$ bulk water samples were collected frequently in $20 \mathrm{~mL}$ vials at the main subglacial outlet within 24 hours on 26/27 July 2000.

Stable hydrogen and oxygen isotopic compositions were determined by mass spectrometry with an analytic accuracy of $\pm 0.34 \%$ in $\delta \mathrm{D}$ and $\pm 0.04 \%$ in $\delta^{18} \mathrm{O}$. Thus, the deuterium excess $\mathrm{d}\left(\mathrm{d}=\delta \mathrm{D}-8 \delta^{18} \mathrm{O}\right)$ has a cumulative analytical accuracy of $\pm 0.47 \%$.

The mineralogical composition and particle-size distribution were determined by X-ray diffraction analysis and laser diffraction, respectively, on 11 thrust-block naled samples and 13 basal ice samples.

\section{RESULTS}

The stable-oxygen-isotope record from the thrust-block naled profile showed a mean $\delta^{18} \mathrm{O}$ composition of $-20.05 \pm 0.52 \%$, which was close to the isotopic range of meteoric glacier ice, $-20.58 \pm 0.93 \%$, and bulk waters emanating from the main outlet, $-19.82 \pm 0.07 \%$ in year 2000. However, basal ice attributed to the stratified facies using the basal ice terminology of Knight (1994) showed mean $\delta^{18} \mathrm{O}$ values of $-16.52 \pm 1.94 \%$ o $(n=9)$, indicating that contrasting formation processes operated at the glacier bed, causing enrichment of the heavy ${ }^{18} \mathrm{O}$ isotope. Thus, as thrust-block naled was not isotopically distinctive from composite meltwaters, it could have been derived from

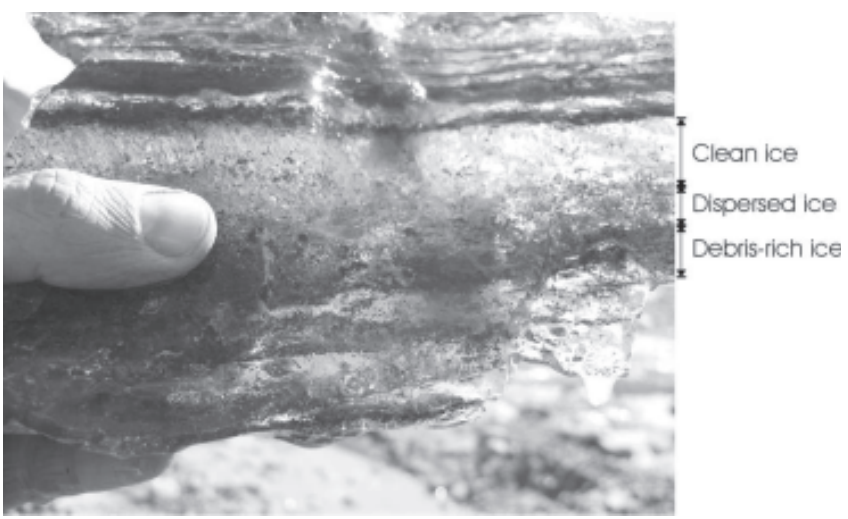

Fig 4. Close-up view of part of thrust-block naled lamination. Beds consist of alternating laminae of debris-rich ice and clean ice, often separated by a lamina of dispersed ice. Note the sub-vertical bubble strings in the clean ice above the thumb, which are interpreted as evidence of metamorphic recrystallization from candle-ice to granular-ice crystallography.

them. In a closed system, i.e. with very limited evaporation in the frigid air and complete freezing of individual naled laminae, the isotopic composition of the naled must be equivalent to that of the source waters. However, naled laminations may contain distinct vertical and lateral variations in $\delta^{18} \mathrm{O}$, as incipient production of frazil ice in supercooled water produces $\delta^{18} \mathrm{O}$ values about $3 \%$ heavier than the parent water composition (Craig, 1961). As the frazil ice accumulates as debris-free slush at the surface and in the distal part of the lamina, successive freezing of the lamina employs increasingly isotopically lighter residual water.

The debris concentration in the thrust-block naled was $4.2 \pm 2.8 \%$ by mass. Although this is a relatively high value for naled assemblages, it is relatively low compared to the debris concentration of the basal stratified ice facies of $57.2 \pm 17.5 \%$ by mass, and to available measurements of basal stratified ice facies from various glaciers (Sharp and others, 1994; Knight and others, 2002). The debris concentration of meteoric glacier ice near the terminus was $0.3 \pm 0.1 \%$ by mass. Figure 5 couples $\delta^{18} \mathrm{O}$ values with debris concentration. There was no correlation between $\delta^{18} \mathrm{O}$ values and debris concentration $(r=0.10 ; p=0.41)$, at least when a $5 \mathrm{~cm}$ interval sampling scale was applied (Fig. 5). This does not preclude the possibility that a correlation prevailed within a single bed, but a more adequate sampling technique would need to be applied to show this.

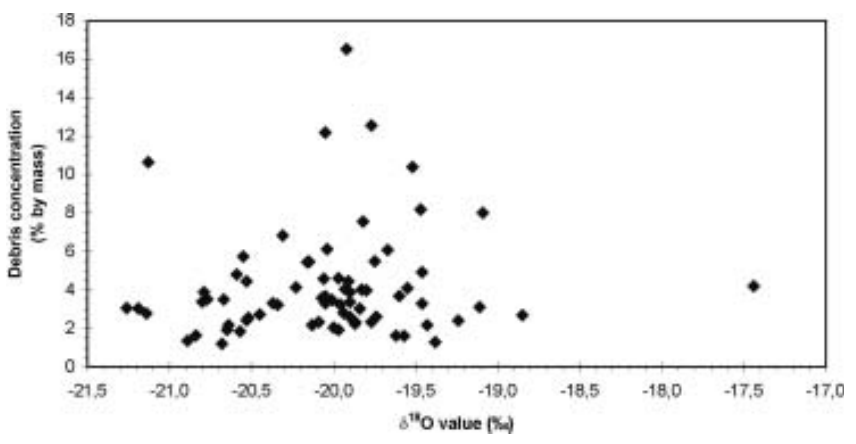

Fig. 5. Scatter plot of $\delta^{18} \mathrm{O}$ values (\%) vs debris concentration (\% by mass). The sample showing a $\delta^{18} \mathrm{O}$ value of $-17.44 \%$ was most likely polluted by rainwater runoff. 

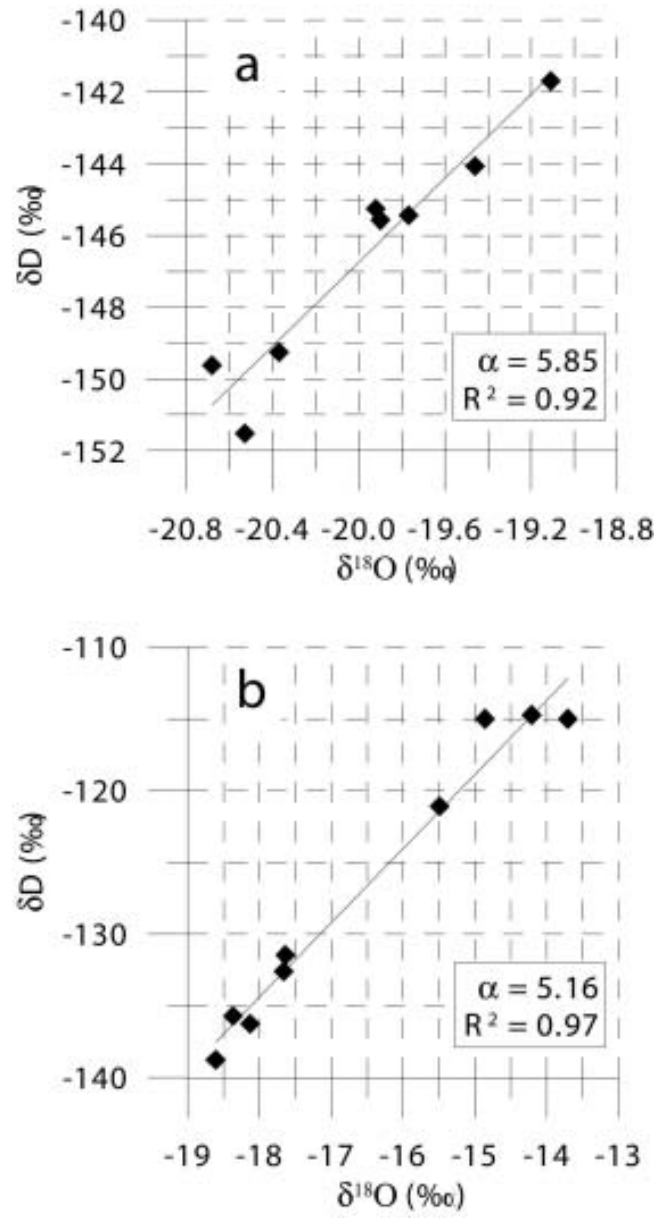

Fig. 6. $\delta \mathrm{D}-\delta^{18} \mathrm{O}$ diagrams showing the relationship in thrust-block naled (a) and basal stratified ice facies (b) at Kuannersuit Glacier.

Co-isotope analysis is applied to discriminate different ice-forming mechanisms. In a $\delta \mathrm{D}-\delta^{18} \mathrm{O}$ diagram (Fig. 6 ), the ice samples of thrust-block naled and basal stratified ice are aligned along freezing slopes $\alpha$ of 5.85 and 5.16, respectively. These slopes diverge from theoretical closed-system freezing slopes of 6.35 and 6.44, respectively (Jouzel and Souchez, 1982, equation 3), and from theoretical opensystem freezing slopes of 6.47 and 6.56, respectively (Souchez and Jouzel, 1984, equation 7), if the median $\delta$ values in the samples are considered as representative for the initial water compositions (Souchez and others, 2004). However, the theoretical freezing slopes accord with the freezing slope of 6.75 found in meteoric glacier ice. Nothing indicates that oxide-hydroxide minerals distort the isotopic signature by ion exchange, as has been shown for basal ice at the margin of the Greenland ice sheet (Souchez and others, 1990). These findings suggest that isotopic fractionation has occurred in both thrust-block naled and basal stratified ice, although their freezing slopes may not be statistically significant from the freezing slope of meteoric glacier ice owing to the relatively small number of samples analyzed (Glasser and Hambrey, 2002).

To differentiate between thrust-block naled and basal stratified ice, the relationship between $\delta \mathrm{D}$ and deuterium excess is considered. Figure 7 a shows that no distinct trend existed in the thrust-block naled, and it is probably better defined as a distribution with a mean $d$ value of $13.18 \pm 1.47 \%$ and independent of $\delta \mathrm{D}$ values. This observation corresponds with a similar absence of $d-\delta D$
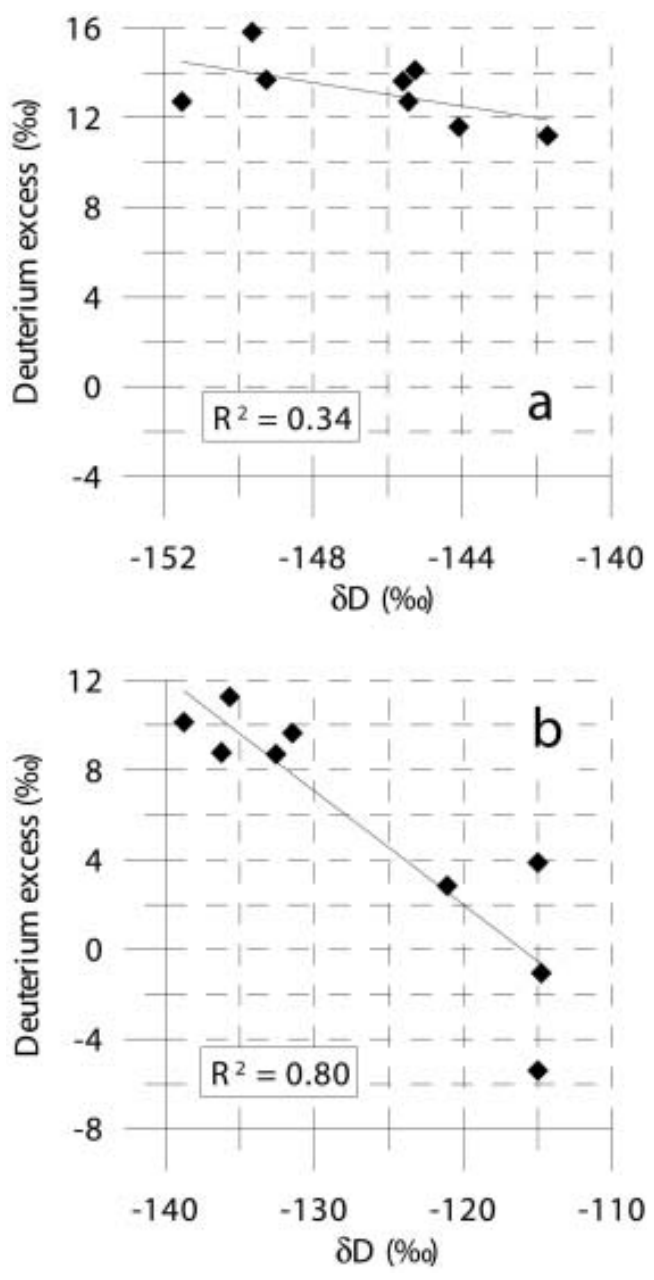

Fig. 7. $d-\delta D$ diagrams of thrust-block naled (a) and basal stratified ice facies (b) at Kuannersuit Glacier.

correlation found in two naledi from north Victoria Land, Antarctica (Souchez and others, 2000). In contrast, an inverse relationship between $\mathrm{d}$ and $\delta \mathrm{D}$ (and $\delta^{18} \mathrm{O}$ ) existed in the basal stratified ice (Fig. 7b). These results imply that while the basal stratified ice formed under boundary conditions dependent on regelation processes, the thrustblock naled was governed by kinetic parameters such as freezing rate, diffusion rate, partial freezing of parent waters, and boundary layer thickness, in addition to non-equilibrium processes and variations in the isotopic composition of parent waters, which will be the case during successive freezing events of thin bulk water layers mixed with snow.

The mineralogical composition of the debris in thrustblock naled varied significantly from the composition of the basal ice in two ways (Table 1). Clay minerals constituted a higher proportion in the thrust-block naled debris compared to the debris in the basal ice, and the plagioclase-topyroxene ratio showed a higher value relative to both the basal ice and the parent plagioclase-rich basalts. These findings suggest that sorting of particles based on specific gravity variations occurred when the naled was formed, whereas the basal ice facilitated no such sorting during its formation. The higher content of clay minerals, primarily smectite aggregates, in thrust-block naled indicates an origin as sequestrated fine-grained debris transported in meltwater, whereas the debris of the basal ice was most likely locally entrained. 
Table 1. Mineralogical composition of thrust-block naled, basal ice and an analysis of basaltic rock matrix at Kuannersuit Glacier, expressed in volume percentage. The amygdaloidal basalts in Kuannersuit Valley contain inclusions of zeolites such as stilbite and heulandite

\begin{tabular}{|c|c|c|c|c|c|c|}
\hline & Number of samples & $\begin{array}{c}\text { Anorthite } \\
\%\end{array}$ & $\begin{array}{c}\text { Augite } \\
\text { \% }\end{array}$ & $\begin{array}{c}\text { Heulandite } \\
\text { \% }\end{array}$ & $\begin{array}{c}\text { Clay minerals } \\
\text { \% }\end{array}$ & $\begin{array}{l}\text { Plagioclase-to- } \\
\text { pyroxene ratio }\end{array}$ \\
\hline Thrust-block naled & 11 & $28.7 \pm 7.1$ & $39.5 \pm 5.3$ & $0.6 \pm 0.8$ & $31.2 \pm 10.8$ & $0.73 \pm 0.14$ \\
\hline Basal ice & 13 & $32.7 \pm 4.0$ & $57.4 \pm 6.2$ & $1.1 \pm 1.2$ & $8.4 \pm 6.1$ & $0.58 \pm 0.10$ \\
\hline
\end{tabular}

The particle-size distribution discriminates thrust-block naled from basal ice facies owing to a relatively higher clay fraction and depletion of silt (Fig. 8). The water velocities during winter runoff are believed to have been sufficient to transport fine-grained material in suspension to the outwash plain. The silt and sand fractions in the thrust-block naled can be explained by aeolian deposition during snowdrift events, or more likely by suspension in upwelling waters during high-discharge pulses. No gravel or larger particles were observed in the thrust-block naled.

\section{DISCUSSION}

The results indicate that, even though thrust-block naled has many similarities with basal ice, it is possible to distinguish naled assemblages. The formation of naled beds composed of a clean-ice lamina above a debris-rich lamina most likely reflects a combination of deposition by gravity and rejection of suspended sediment from the freezing front within a water layer, which emerges at the surface of a growing naled assemblage and flows in the frigid air. The dispersed lamina can have formed either during in situ freezing, capturing aggregates in ice crystal boundaries, or as a consequence of metamorphosis during compression, where migrating water entrains debris at the debris-rich lamina interface. Recrystallization of sub-vertical candle ice into granular ice crystals, presumably caused by compression of the naled during stacking, makes it difficult to recognize thrust-block naled ice from basal ice. The relatively high debris concentration in surge-related naled is a consequence of dramatic changes in the glacier drainage configuration, the improved access to subglacially comminuted debris and the enhanced hydraulic potential in the proglacial area. Similar debris concentrations and the interlamination sequence with basal debris-rich ice, dispersed ice and top clean ice probably resemble basal ice formed by segregated congelation processes at the ice-sediment interface. However, the particle-size distribution, the absence of gravel, the mineralogical composition and the isotopic signature favour fluvial sediment transfer during slow water velocity.

The formation process of thrust-block naled during surge advance is most likely similar to the formation of thrustblock moraines (e.g. Hagen, 1988; Evans and England, 1991; Fitzsimons, 1996). In winter, the coupling of horizontal pressure on proglacial naled and frozen sediments, caused by the advancing glacier, and upward vertical pressure promoted by the build-up of a high hydraulic potential below proglacial naled produces stress release by thrusting and stacking of naled blocks. The presence of proglacial naled of prominent thickness can have implications for whether landforms like thrust-block moraines form in front of surge-type glaciers, if the proglacial stresses are transmitted within the upper layers. Assuming that the increased proglacial naled thickness, owing to a surge event, facilitates an unfrozen water-saturated zone within the outwash deposits below, this zone can act as a lubricating boundary layer and, thus, be an obvious location for shearing to take place. At Kuannersuit Glacier, the shear planes were situated in the top layer of the outwash deposits, thereby separating the individual blocks by a horizon rich in boulders and gravel deposits.

Incorporation of naled beneath basal ice seems to be a plausible process below a transgressing surging glacier. Although it is circumstantial, the situation at Kuannersuit Glacier suggests that the glacier overrode annual thrustblock naledi during its active surge phase, only preserving the 1998/99 naled stacked in front of the glacier. Naled entrained and transported at the start of or during the surge event would be as heavily deformed and sheared as the basal ice, and mixed with dry-calved glacier ice and generated basal ice. Such naled will most likely be beyond recognition. Thus, the lack of internal deformation in the thrust-block naled indicates that the thrust-block naled formed during the termination of the surge event. Hambrey (1984) speculated that proglacial buried naled could be coupled to the bed of an advancing glacier and thereby

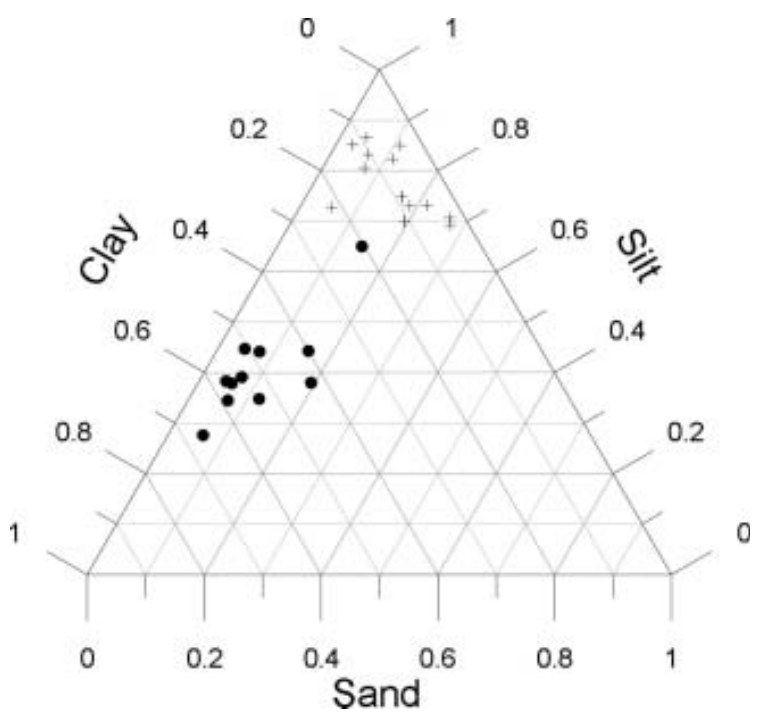

Fig. 8. Particle-size distribution (\% mass) of debris in thrust-block naled (circles) and basal ice (crosses) at Kuannersuit Glacier. 
explain some of the debris-rich stratification in basal ice layers. Surge-type glaciers are associated with more debrisrich basal ice layers relative to non-surge-type glaciers (e.g. Clapperton, 1975), a process related to regelation ice produced by low-pressure refreezing in subglacial cavities. Parts of these basal ice layers may actually be recrystallized overridden naled, and a thorough re-examination of basal ice beneath and at the margin of surge-type glaciers is required in order to elucidate this issue.

\section{CONCLUSIONS}

This study has identified thrust-block naled stacked in front of Kuannersuit Glacier during the termination of a major terrestrial surge event. The thrust-block naled had retained the debris-rich lamination observed in proglacial naled related to the surge, although compression during stacking had altered ice crystallography. The thrust-block naled was distinguishable from basal stratified ice facies owing to lack of internal deformation structures, relatively low debris content, a more clay-rich particle-size distribution with lack of gravel and larger particles, a plagioclase-to-pyroxene ratio indicating that a sorting process favoured plagioclase particles with low specific gravity at the expense of heavier pyroxene particles, and no correlation between $\delta \mathrm{D}$ and deuterium excess d. Stable-oxygen-isotope analyses provided no signature differentiable from bulk meltwater or other ice facies.

Surge-type glaciers have significant potential for formation of thrust-block naled owing to rapid advance of the terminus and enhanced winter runoff during the active surge phase. Stacking and subsequent overriding of naled may have implications for the interpretation of basal ice layers of surge-type glaciers. However, thrust-block naled is not an unequivocal diagnostic criterion for surge-type glaciers, as non-surging glaciers have some capabilities for production of proglacial stresses during mass-balance induced rapid advance.

\section{ACKNOWLEDGEMENTS}

We thank C. Hammer of the Niels Bohr Institute, Copenhagen, Denmark, for providing the analyses of the oxygen isotope samples. Arctic Station in Qeqertarsuaq, Disko Island, gave local logistical support. R. Nielsen is acknowledged for map design. We thank I. Willis, P. Knight and N. Glasser for valuable comments and suggestions on an earlier version of the paper. The research was funded by grants from the Commission for Scientific Research in Greenland (KVUG) and from Carlsbergfondet. J.C. Yde received financial support from the International Research School of Water Resources (FIVA).

\section{REFERENCES}

Åkerman, J. 1982. Studies on naledi (icings) in West Spitsbergen. In Proceedings of the Fourth Canadian Permafrost Conference. Ottawa, National Research Council of Canada, 189-202.
Baranowski, S. 1982. Naled ice in front of some Spitsbergen glaciers. J. Glaciol., 28(98), 211-214.

Bennett, M.R., D. Huddart, M.J. Hambrey and J.F. Ghienne. 1998. Modification of braided outwash surfaces by aufeis: an example from Pedersenbreen, Svalbard. Z. Geomorph., 42(1), 1-20.

Clapperton, C.M. 1975. The debris content of surging glaciers in Svalbard and Iceland. J. Glaciol., 14(72), 395-406.

Craig, H. 1961. Isotopic variations in meteoric waters. Science, 133(3465), 1702-1703.

Evans, D.J.A. and J. England. 1991. Canadian landform examples 19. High Arctic thrust block moraines. Can. Geogr., 35(1), 93-97.

Evans, D.J.A. and B.R. Rea. 1999. Geomorphology and sedimentology of surging glaciers: a land-systems approach. Ann. Glaciol., 28, 75-82.

Fitzsimons, S.J. 1996. Formation of thrust-block moraines at the margins of dry-based glaciers, south Victoria Land, Antarctica. Ann. Glaciol., 22, 68-74.

Glasser, N.F. and M.J. Hambrey. 2002. $\delta \mathrm{D}-\delta^{18} \mathrm{O}$ relationships on a polythermal valley glacier: Midtre Lovénbreen, Svalbard. Polar Res., 21(1), 123-131.

Hagen, J.O. 1988. Glacier surge in Svalbard with examples from Usherbreen. Nor. Geogr. Tidsskr., 42(4), 203-213.

Hambrey, M.J. 1984. Sedimentary processes and buried ice phenomena in the pro-glacial areas of Spitsbergen glaciers. J. Glaciol., 30(104), 116-119.

Jouzel, J. and R.A. Souchez. 1982. Melting-refreezing at the glacier sole and the isotopic composition of the ice. J. Glaciol., 28(98), $35-42$.

Knight, P.G. 1994. Two-facies interpretation of the basal layer of the Greenland ice sheet contributes to a unified model of basal ice formation. Geology [Boulder], 22(11), 971-974.

Knight, P.G., R.I. Waller, C.J. Patterson, A.P. Jones and Z.P. Robinson. 2002. Discharge of debris from ice at the margin of the Greenland ice sheet. J. Glaciol., 48(161), 192-198.

Liestøl, O. 1969. Glacier surges in West Spitsbergen. Can. J. Earth Sci., 6(4), 895-897.

Sharp, M., J. Jouzel, B. Hubbard and W. Lawson. 1994. The character, structure and origin of the basal ice layer of a surgetype glacier. J. Glaciol., 40(135), 327-340.

Souchez, R.A. and J. Jouzel. 1984. On the isotopic composition in $\delta \mathrm{D}$ and $\delta^{18} \mathrm{O}$ of water and ice during freezing. J. Glaciol., 30(106), 369-372.

Souchez, R., M. Lemmens, R. Lorrain, J.L. Tison, J. Jouzel and D. Sugden. 1990. Influence of hydroxyl-bearing minerals on the isotopic composition of ice from the basal zone of an ice sheet. Nature, 345(6272), 244-246.

Souchez, R.A., J. Jouzel, R. Lorrain, S. Sleewaegen, M. Stievenard and V. Verbeke. 2000. A kinetic isotope effect during ice formation by water freezing. Geophys. Res. Lett., 27(13), 1923-1926.

Souchez, R., D. Samyn, R. Lorrain, F. Pattyn and S. Fitzsimons. 2004. An isotopic model for basal freeze-on associated with subglacial upward flow of pore water. Geophys. Res. Lett., 31(2), L02401. (10.1029/2003GL018861.)

Steenstrup, K.J.V. 1901. Beretning om en Undersøgelsesrejse til Øen Disko i Sommeren 1898. Medd. Grønl., 24(3), 249-306.

Weidick, A. 1988. Surging glaciers in Greenland: a status. Grønlands Geologiske Undersøgelse. Rapport 140, 106-110.

Yde, J.C., N.T. Knudsen and O.B. Nielsen. 2005. Glacier hydrochemistry, solute provenance, and chemical denudation at a surge-type glacier in Kuannersuit Kuussuat, Disko Island, West Greenland. J. Hydrol., 300(1/4), 172-187. 